\title{
Tax Avoidance Jangka Panjang di Indonesia
}

\author{
Herlan dan Tryas Chasbiandani \\ Fakultas Ekonomi dan Bisnis Universitas Pancasila Jakarta \\ Jl. Raya Lenteng Agung No.56-80, Srengseng Sawah, Jagakarsa, Jakarta, 12640, Indonesia
}

\section{Info Article}

Keywords:

Long Run Cash; Long Run Effective; Long Run Tax; Tax avoidance.

ISSN (print) : 2598-7763 ISSN (online): 2598-7771

\footnotetext{
$\triangle$ Corresponding Author: Herlan

Tel. /Fax. 0816-946-278

E-mail:

herlan@univpancasila.ac.id
}

\begin{abstract}
Abtract
Long run tax avoidance is a method by Dyreng et al (2008), which can show the real tax avoidance activity by the firms. The research aims to analyze long-run tax avoidance in Indonesia, for the factor that influences long-run tax avoidance and the effect of tax avoidance on firm value. The research was conducted for nonbanking and financial firms in Indonesia Stock Exchange for the period 2015-2016. The analytical used is the fixed-effect method. The result of this research indicates that short-run tax avoidance has a positive influence on long-run tax avoidance. The sample of this research, the short-run tax avoidance is persisted over a period.
\end{abstract}

Citation: Herlan dan Tryas Chasbiandani. (2019). Tax Avoidance Jangka Panjang di Indonesia. AFRE Accounting and Financial Review, 2 (1)

\begin{abstract}
Abstraks
Tax avoidance jangka panjang merupakan suatu model pengukuran tax avoidance usulan Dyreng et al. (2008), yang dianggap mampu menggambarkan aktivitas nyata dari tax avoidance yang dilakukan oleh perusahaan. Tujuan dari penelitian ini adalah untuk menganalisis tax avoidance jangka panjang di Indonesia, mengenai faktor yang mempengaruhi dan pengaruhnya terhadap nilai perusahaan. Penelitian ini menggunakan sampel perusahaan non perbankan dan keuangan yang terdaftar di Bursa Efek Indonesia periode 2015-2016. Analisis dalam penelitian ini menggunakan metode efek tetap. Hasil dari penelitian ini menunjukkan bahwa tax avoidance jangka pendek berpengaruh positif terhadap tax avoidance jangka panjang. Pada perusahaan dalam sampel penelitian ini, tax avoidace jangka pendek yang dilakukan bersifat persisten dari waktu ke waktu, dimana tax avoidance yang lebih tinggi cenderung lebih persisten.
\end{abstract}

JEL Classification G11, G24

DOI: https://doi.org/10.26905/afr.v2i1.3171

\section{PENDAHULUAN}

Pajak merupakan sumber penerimaan negara dan memiliki peranan sebagai sumber dana bagi pembiayaan negara, sehingga peranan pajak seharusnya ditingkatkan secara optimal dalam rangka mempercepat laju pertumbuhan Indonesia. Kewajiban membayar pajak di Indonesia bersubjek pada dua hal, yaitu subjek pajak orang pribadi dan subjek pajak badan. Dengan sistem self assessment yang digunakan Indonesia, hal tersebut menjadikan wajib pajak menentukan sendiri jumlah pajak yang harus dibayarkan ke kas negara. Dalam hal wajib pajak badan (perusahaan), pajak menjadi beban yang mengurangi laba perusahaan, sehingga perusahaan melakukan tax planning dalam usahanya untuk mengurangi jumlah pajak yang harus dibayarkan perusahaan. Tax planning merupakan tindakan penstrukturan yang terkait dengan konsekuensi potensi pajaknya, yang tekanannya kepada pengendalian setiap transaksi yang ada konsekuensi pajaknya dengan tujuan mengefisienkan jumlah pajak yang akan di transfer ke pemerintah.

Manajemen pajak menjadi factor penting bagi perusahaan untuk mningkatkan kinerja perusahaan. Manajemen pajak yang baik akan menekan 
beban pajak yang harus dibayar oleh perusahaan (Amri, 2017). Tax avoidance merupakan upaya wajib pajak untuk tidak melakukan perbuatan yang dikenakan pajak atau upaya-upaya yang masih dalam kerangka ketentuan peraturan perundangundangan perpajakan untuk memper-kecil jumlah pajak yang terhutang.

Tax avoidance menjadi hal yang menarik untuk diteliti karena belum adanya definisi universal dari tax avoidance. Dyreng, at al. (2010) tax avoidance sebagai pengurangan jumlah pajak eksplisit, dimana tax avoidance merupakan rangkai aktivitas perencanaan pajak. Tax avoidance berhubungan langsung dengan kepentingan shareholder. Tax avoidance juga dapat menggambarkan suatu bentuk permasalahan keagenan, dimana keputusan manajer dapat mencerminkan adanya kepentingan pribadi manajer dengan adanya pemisahan kepemilikan dan pemisahan pengendalian. Dengan memahami bagaimana governance terkait pada tax avoi-dance, akan diperoleh pemahaman yang lebih baik mengenai bagaimana cara kerja governance dalam jangka panjang dan jangka pendek.

Beberapa penelitian terkait dengan tax avoidance dan CSR dan koneksi politik. Penelitian Pratiwi (2017) menunjukkan ada korelasi positif antara CSR dengan tax avoidance. Sedangkan penelitian Irawan, Sularso dan Farida (2017), Damayanti dan Susanto (2015) menemukan bahwa ukuran perusahaan dan ROA berpengaruh positif terhadap tax avoidance, sedangkan kualitas audit berengaruh negatif terhadap tax avoidance. Namun penelitian Damayanti dan Susanto (2015) menemukan kuaitas audit tidak berpengaruh pada tax avoidance. Temuan penelitian Yuniarwati, Ardana, Dewi, dan Lin (2017) menunjukkaan bahwa ukuran perusahaan tidak berpengaruh terhadap tax avoidance.

Masih minimnya penelitian mengenai tindakan tax avoidance perusahaan, terutama penelitian yang mengkaji tax avoidance perusahaan dalam jangka waktu yang lama memotivasi peneliti untuk melakukan penelitian terkait. Peneliti menggunakan avoidance karena tujuannya untuk mengetahui kemampuan perusahaan dalam melakukan penghindaran pajak atas pendapatan yang dilaporkan kepada pemegang saham, bukan untuk melihat apakah tindakan itu benar atau salah. Peneliti berniat untuk mengajukan penelitian mengenai tax avoidance jangka panjang di Indonesia. Mengkaji kondisi ETR di Indonesia dalam jangka panjang menjadi hal yang menarik dan dapat memberikan tambahan informasi mengenai kondisi perpajakan di Indonesia, terutama pajak yang dibayarkan oleh perusahaan yang sudah go public serta karakteristik perusahaan sebagai faktor yang mempengaruhi tax avoidance jangka panjang perusahaan. Sampel yang digunakan dalam penelitian ini adalah seluruh perusahaan yang terdaftar di Bursa Efek Indonesia periode 2007 sampai dengan 2016. Kontribusi dari penelitian ini adalah menambah literatur terkait tax avoidance di Indonesia dalam jangka panjang, sehingga dapat menjadi evaluasi atas aktivitas tax planning yang dilakukan oleh perusahaan publik di Indonesia.

\section{PENGEMBANGAN HIPOTESIS}

Tax avoidance yang dilakukan oleh perusahaan telah banyak dikaji dalam beberapa penelitian. Terdapat berbagai macam model pengukuran tax avoidance, antara lain: 1) Effective tax rates (ETR). ETR dihitung dengan menghitung ratio kewajiban pajak dengan pendapatan sebelum pajak atau cash flow. Ratio ini menggambarkan rata-rata tarif pajak perrupiah dari income ataupun cash flow. Kelemahan dari pengukuran tax avoidance menggunakan ETR adalah ketidakmampuan ETR dalam menangkap tindakan tax avoidance yang dilakukan perusahaan ketika perusahaan melaporkan pendapatan akutansi yang rendah, menyamakan dengan pendapatan yang dilaporkan dalam laporan pajak. 2) Long Run Effective tax rates (LRETR). Long run cash ETR merupakan model yang dikembangkan oleh Dyreng, et. al. (2008). Model ini merupakan jawaban atas ketidakmampuan GAAP ETR dalam menghitung tax avoidance yang dilakukan oleh perusahaan. Dimana GAAP merupakan nisbah antara Total Tax Expense dengan Pre Tax Income. Kelemahan atau permasalahan pada GAA ETR adalah, antara lain: a) GAAP ETR hanya berdasarkan pada data 1 periode, padahal sangat dimungkinkan terjadi variasi dalam ETR tahunan. Hal tersebut dapat menimbulkan bias dalam perhitungan dan perilaku tax avoidance yang dilakukan oleh perusahaan; b) Tax expense merupakan jumlah dari beban pajak saat ini dan beban pajak tangguhan dimana pajak tangguhan menggambarkan jumlah pajak yang akan dibayarkan atau dikembalikan dimasa yang akan datang sebagai konsekuensi atas adanya temporary different. Karenanya GAAP ETR tidak dapat mencerminkan tax avoidance perusahaan. Mengatasi permasalahan tersebut, Dyreng, et. al. (2008) menggunakan ukuran long run cash ETR sebagai pengukuran dari tax avoidance perusahaan. dalam long run cash ETR, pengukuran ETR dila-kukan dalam jangka waktu yang panjang, misalnya 10 tahun. Dengan menjumlahkan total cash tax paid perusahaan dalam waktu 10 tahun kemudain mem- 
baginya dengan total pre tax income (yang sudah dikurangi dengan special item) dengan jangka waktu yang sama, hal tersebut dapat menggambarkan kondisi ETR yang lebih mendekati biaya pajak perusahaan dalam jangka panjang. Modifikasi ini tidak sama dengan merata-ratakan ETR tahunan dalam jangka waktu tertentu karena hal tersebut dapat menimbulkan kesalahan penilaian (overweight). Ketika merata-ratakan mungkin sekali ETR tahunan perusahaan tersebut terlalu tinggi, terlalu kecil atau bahkan bisa juga negatif. Hal tersebut dapat menimbulkan bias. Mengukur ETR dengan menggunakan Cash tax paid, bukan menggunakan GAAP tax expense. Cash tax paid dapat ditemukan di laporan keuangan dalam statement of cash flow perusahaan.

Long Run ETR $=\frac{\sum(\text { worldwide cash taxes paid })}{\sum(\text { worldwide total pre tax accounting income })}$

\section{Tax avoidance Jangka Pendek dan Tax avoidance Jangka Panjang}

Dyreng et. al. (2008) melakukan terobosan mengenai pengukuran tax avoidance perusahaan yang diukur dengan cash Effective tax rate (ETR) jangka panjang. Dyreng, et. al. (2008) menyatakan bahwa Cash ETR tahunan bukanlah prediktor yang baik dalam memprediksi cash ETR jangka panjang, oleh sebab itu Dyreng et. al. (2008) menggunakan cash ETR jangka panjang dengan periode 10 tahun. Selain itu, cash ETR tahunan yang rendah lebih persisten dibanding cash ETR tahunan yang tinggi. Total sampel dalam penelitian yang dilakukan oleh Dyreng et. al. (2008) adalah 1.891 tahun perusahaan dengan periode penelitian dari tahun 1995-2000, dimana dalam pengujiannya me-ngenai persistensi dan reliabilitas dari pengukuran tax avoidance jangka panjang, Dyreng et. al. (2008) membagi sampel dalam 3 kelompok. Kelompok pertama adalah peru-sahaan dengan cash ETR tahun pertama kurang dari sama dengan $20 \%$. Kelompok kedua berisi perusahaan dengan cash ETR tahun pertamanya antara 20\% hingga 40\%. Kelompok ketiga adalah perusahaan yang memiliki cash ETR tahun pertamanya lebih dari $40 \%$. Pembagian sampel ini hanya berdasarkan pada variasi dari cash ETR pada sampel penelitian. Kemudian peneliti melakukan pengujian mengenai hubungan langsung antara cash ETR1 dengan cash ETR10. Hasilnya baik untuk keseluruhan observasi mau-pun dengan masingmasing kelompoknya, cash ETR1 berpengaruh signifikan positif dengan cash ETR10.

$\mathrm{H}_{1}$ : Tax avoidance jangka pendek berpengaruh positif terhadap tax avoidance jangka panjang.

\section{Persistensi Tax avoidance perusahaan}

Penelitian yang dilakukan oleh Dyreng $e$, al (2008) menguji persistensi dari ETR jangka pendek sebagai proksi dari tax avoidance jangka pendek yang dilakukan oleh perusahaan. Dengan melakukan regresi cash ETR $R_{\mathrm{t}+1}$ dengan cash ETR $R_{\mathrm{t}}$, Dyreng et. al., (2008) menemukan bahwa cash ETR cenderung persisten. Di Indonesia, perencanaan pajak dalam perusahaan masih menjadi topik yang hangat, dalam usaha efektivitas dan efisiensi pembayaran pajak.

Dyreng et. al. (2008) juga melakukan pengelom-pokkan berdasarkan ETR tahunan perusahaan menjadi tiga kelompok, yaitu redah $(<20 \%)$, sedang $(20 \%-40 \%)$ dan tinggi (> 40\%). Pengelompokkan tersebut hanya didasarkan pada sebaran ETR dalam sampel penelitian. Hasil dari pengujian berkelompok menunjukkan bahwa pada perusahaan dengan cash ETR rendah dan cash ETR sedang, cash ETR tahunan cenderung presisten. Namun, untuk perusahaan dengan cash ETR yang tinggi, cash ETR tahunannya terbukti tidak persisten.

$\mathrm{H}_{2}$ : Tax avoidance jangka pendek perusahaan persisten dari waktu ke waktu

$\mathrm{H}_{3}$ : Perusahaan dengan ETR tahunan rendah, ETR tahunannya lebih persisten dari tahun ke tahun

\section{DATA DAN METODE}

Penelitian ini menggabungkan pengujian yang dilakukan oleh Dyreng, et. al. (2008), Richardson dan Lanis (2007) dan pengujian yang dilakukan oleh Desai dan Dharmapala (2006). Dengan kompre-hensivitas literatur yang menjadi acuan, beberapa hal baru yang muncul dalam penelitian ini antara lain: 1) Kajian mengenai ETR perusahaan di Indonesia secara jangka panjang; 2) Pengaruh perilaku tax avoidance perusahaan dalam jangka panjang terhadap nilai perusahaan di Indonesia; 3) Penjelasan deskriptif mengenai perilaku tax avoidance perusahaan yang terdaftar di Bursa Efek Indonesia dan kaitannya dengan ETR jangka panjang dan jangka pendek.

\section{Model Empiris dan Variabel Penelitian}

Model empiris dalam penelitian ini seluruh variabel independen yang diduga mempengaruhi variabel dependen dimasukkan secara bersamasama untuk melihat pengaruh dari masing-masing variabel independen terhadap variabel dependen. Penelitian ini menggunakan 2 model empiris, pada model 1 dan model 2 .

LRTA $=\alpha+\beta$ SRTA $+e$. 
Keterangan: LRTA= adalah rasio dari jumlah pajak yang dibayarkan oleh perusahaan dibagi dengan pre tax income yang sudah dikurangi oleh spesial item dalam jangka panjang (10 tahun); SRTA= adalah rasio jumlah pajak yang dibayarkan oleh perusahaan dibagi dengan pre tax income yang sudah dikurangi spesial item dalam jangka pendek (1 tahun)

$$
S R T A_{t+1}=\alpha+\beta_{1} S_{R T A_{t}}+\beta_{3} S_{R T A_{t}} * d d_{-} S R T A+e .
$$

Keterangan: SRTA $_{t+1}=$ rasio dari jumlah pajak yang dibayarkan oleh perusahaan dibagi dengan pre tax income pada $\mathrm{t}+1$; 2) $\mathrm{SRTA}_{\mathrm{t}}=$ rasio jumlah pajak yang dibayarkan oleh perusahaan dibagi dengan pre tax income tahunan; d_SRTA= dummy variabel untuk membedakan besar kecilnya tax avoidance jangka pendek perusahaan dimana 1 untuk SRTA rendah (dibawah rata-rata) dan 0 untuk SRTA tinggi (diatas rata-rata).

Variabel dalam penelitian ini adalah tax avoidance jangka panjang yang diukur dengan ETR jangka panjang. Awalnya peneliti menggunakan cash ETR jangka panjang, sesuai dengan perhitungan yang dilakukan oleh Dyreng et. al. (2008). Namun karena hasilnya terlalu tinggi bahkan diatas $100 \%$, maka peneliti menggunakan GAAP ETR jangka panjang. Tingginya cash ETR pada perusahaan di Indonesia kemungkinan besar disebabkan oleh pelaporan cash tax paid dalam cash flow statement tidak hanya melaporkan pajak atas penghasilan yang dibayarkan, namun juga pajak yang lainnya sehingga tidak mencerminkan pajak atas penghasilan yang sebenarnya harus dibayarkan oleh perusahaan. Tax avoidance jangka panjang merupakan model yang telah dikembangkan oleh Dyreng, et. al. (2008).

$$
E T R_{t}=\frac{\sum \text { income }_{\text {tax }}}{\left(\sum \text { pre tax } \text { income }_{t}-\sum \text { special item }_{t}\right)}
$$

Populasi dari penelitian ini adalah seluruh perusahaan yang terdaftar dalam Bursa Efek Indonesia, kecuali untuk sektor perbankan dan keu- angan. Sampel yang digunakan adalah data kuantitatif yaitu data yang diukur dalam suatu skala numerik. Teknik sampel yang digunakan dalam penelitian ini adalah metode purposive sampling, yaitu sample yang ditarik dengan menggunakan pertimbangan. Kriteria pemilihan sampel yang akan diteliti adalah perusahaan yang memenuhi rasio-rasio keuangan yang digunakan sebagai pengukur variabel penelitian dan perusahaan dengan pre tax income selama 11 tahun yang positif.

\section{HASIL}

Dalam penelitian ini, tax avoidance perusahaan di hitung berdasarkan pada tax avoidance jangka panjang dengan periode waktu 10 tahun. Selain itu peneliti juga mengkaji tax avoidance jangka panjang untuk periode kumulatif 8 tahun, 5 tahun dan 4 tahun. Statistik deskriptif untuk perhitungan tax avoidance jangka pendek dan tax avoidance jangka panjang tersaji dalam tabel 1 . Pada tax avoidance jangka pendek, nilai rata-rata tarif pajak efektif (ETR) tahunan yang dibayarkan oleh perusahaan adalah $29,12 \%$. Nilai tertinggi untuk tax avoidance jangka pendek perusahaan adalah $98,80 \%$ dan nilai terendahnya adalah $0 \%$, yang berarti perusahaan tersebut tidak memiliki income tax. Nilai standar deviasi pada tax avoidance jangka pendek paling tinggi dibanding dengan pengukuran tax avoidance lainnya, menunjukkan bahwa nilai tax avoidance jangka pendek dalam sampel penelitian ini bervariasi.

Untuk tax avoidance jangka panjang dengan jangka waktu 4 tahun, rata-rata long run ETR yang dibayarkan oleh perusahaan adalah 28,50\% dengan nilai median $28,50 \%$. Dekatnya nilai rata-rata dengan nilai median menunjukkan variansi tax avoidance jangka panjang pada periode 4 tahun ini cukup stabil. Nilai tertinggi dari tax avoidance jangka panjang dengan periode kumualtif 4 tahun adalah 96,77 dengan nilai terendahnya $0,16 \%$.

Tabel 1. Tax Avoidance Jangka Panjang

\begin{tabular}{lllllll}
\hline \multicolumn{1}{c}{ Tax avoidance } & Obs & Rata-rata & Median & Stand, Dev & Tertinggi & Terendah \\
\hline SRTA & 1155 & 0,291195 & 0,285947 & 0,140755296 & 0,968011 \\
LRTA4 & 840 & 0,285054 & 0,285059 & 0,121687859 & 0,967557 \\
LRTA5 & 735 & 0,283745 & 0,286418 & 0,116962475 & 0,974597 \\
LRTA8 & 420 & 0,284487 & 0,284318 & 0,110312315 & 0,859459 \\
LRTA10 & 210 & 0,289658 & 0,279814 & 0,119711346 & 0,961148 & 0,000633 \\
\hline Diman
\end{tabular}

Dimana: SRTA merupakan tax avoidance jangka pendek yang diukur dengan ETR tahunan. LRTA 4 merupakan tax avoidance jangka panjang perusahaan dengan perhitungan ETR kumulatif 4 tahun. LRTA 5 merupakan tax avoidance jangka panjang perusahaan dengan perhitungan ETR kumulatif 5 tahun. LRTA 8 merupakan tax avoidance jangka panjang perusahaan dengan perhitungan ETR kumulatif 8 tahun. LRTA10 merupakan tax avoidance jangka panjang perusahaan dengan perhitungan ETR kumulatif 10 tahun.

Pengukuran tax avoidance lainnya, menun- jukkan bahwa nilai tax avoidance jangka pendek da- 
lam sampel penelitian ini bervariasi. Untuk tax avoidance jangka panjang dengan jangka waktu 4 tahun, rata-rata long run ETR yang dibayarkan oleh perusahaan adalah 28,50\% dengan nilai median $28,50 \%$. Dekatnya nilai rata-rata dengan nilai me-dian menunjukkan variansi tax avoidance jangka panjang pada periode 4 tahun ini cukup stabil. Nilai tertinggi dari tax avoidance jangka panjang dengan periode kumualtif 4 tahun adalah 96,77 dengan nilai terendahnya $0,16 \%$.

Pada tax avoidance jangka panjang dengan periode kumulatif 5 tahun, rata-rata long run ETR perusahaan adalah $28,37 \%$ dengan nilai tengah $28,64 \%$ dan nilai tertinggi $97,46 \%$. Nilai terendah pada long run ETR yang dibayarkan oleh perusahaan adalah $0,06 \%$ dengan nilai standar deviasi 0,116962 . Untuk tax avoidance jangka panjang yang dihitung dengan kumulatif 8 tahun, nilai rata-rata ETR jangka panjangnya adalah $28,45 \%$ dengan nilai tengah $28,43 \%$. Nilai tertinggi tax avoidance jangka panjang yang dibayarkan oleh perusahaan adalah $85,60 \%$ dan nilai terendahnya $0,21 \%$. Standar deviasi dalam perhitungan tax avoidance jangka panjang kumulatif 8 tahun memiliki nilai paling kecil. Menunjukkan bahwa nilai LRTA8 dalam sampel penelitian tidak begitu bervariasi. Terakhir pengukuran tax avoidance dengan periode kumulatif 10 tahun. Periode ini berdasarkan pada perhitungan Dyreng et al. (2008) yang menghitung tax avoidance jangka panjang perusahaan berdasarkan pada long run ETR perusahaan dalam jangka waktu 10 tahun. Nilai rata-rata untuk tax avoidance jangka panjang dengan periode 10 tahun adalah $28,30 \%$ dan nilai tengah $27,30 \%$ serta standar deviasi 0,11971 . Nilai tertinggi tax avoidance jangka panjang periode 10 tahun adalah $96,11 \%$ dan nilai terendahnya $4,70 \%$. Peneliti mencoba membandingkan perhitungan tax avoidance perusahaan, yaitu antara tax avoidance jangka pendek, tax avoidance jangka panjang kumulatif 4 tahun, tax avoidance jangka panjang kumulatif 5 tahun, tax avoidance jangka panjang kumulatif 8 tahun dan tax avoidance jangka panjang kumulatif 10 tahun. Gambar tingkat tax avoidance disajikan pada gambar 1 .

Nilai rata-rata SRTA dan LRTA disajikan pada tabel 2. Dimana nilai SRTA tertinggi terjadi pada tahun 2014. Sedangkan nilai LRTA tertinggi pada LRTA8 pada tahun 2015.

Tax avoidance yang diukur dengan tarif pajak efektif perusahaan secara jangka panjang, yaitu kumulatif 10 tahun, perusahaan sampel menunjukkan bahwa kebanyakan perusahaan dalam sampel penelitian ini memiliki tarif pajak efektif berkisar pada 20\%-30\%. Gambar 2 dan gambar 3 menggambarkan sebaran tarif pajak efektif perusahaan sampel sebagai proksi dari tax avoidance jangka panjang.

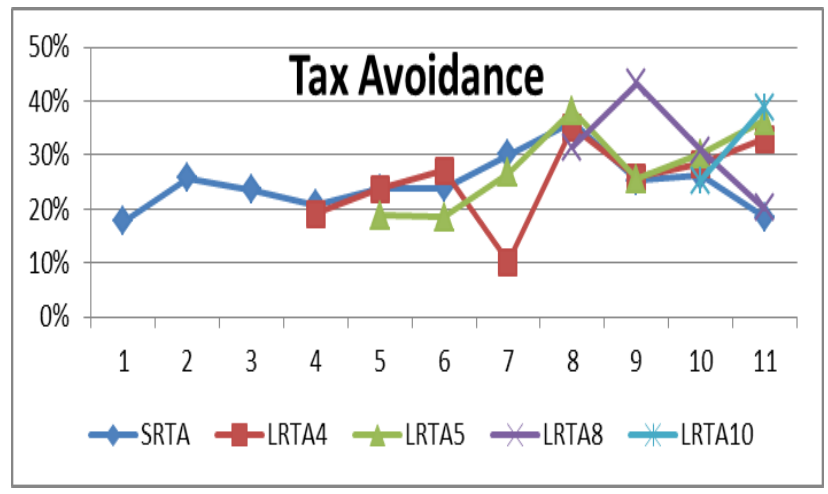

Gambar 1. Tax Avoidance

Tabel 2. Nilai Rata-Rata Short Run dan Long Run Tax Avoidance

\begin{tabular}{cccccc}
\hline Tahun & \multicolumn{5}{c}{ SRTA } \\
\hline 2007 & $17,78 \%$ & LRTA4 & LRTA5 & LRTA8 & LRTA10 \\
2008 & $25,75 \%$ & & & & \\
2009 & $23,62 \%$ & & & & \\
2010 & $20,74 \%$ & & & & \\
2011 & $23,66 \%$ & $19,12 \%$ & & & \\
2012 & $23,95 \%$ & $23,73 \%$ & $18,74 \%$ & & \\
2013 & $30,09 \%$ & $27,09 \%$ & $18,47 \%$ & & \\
2014 & $36,21 \%$ & $10,10 \%$ & $26,71 \%$ & & \\
2015 & $25,22 \%$ & $35,19 \%$ & $38,31 \%$ & $31,40 \%$ & \\
2016 & $26,19 \%$ & $25,95 \%$ & $25,51 \%$ & $43,27 \%$ & \\
2017 & $18,48 \%$ & $28,42 \%$ & $30,27 \%$ & $30,89 \%$ & $25,32 \%$ \\
\hline
\end{tabular}



Gambar 2. Tarif Pajak Efektif Jangka Panjang Tahun 2015

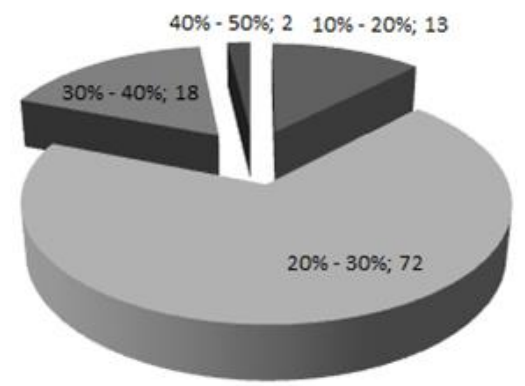

Gambar 3. Tarif Pajak Efektif Jangka Panjang Tahun 2016 
Peneliti kemudian mengelompokkan sampel kedalam 3 jenis industri utama yang di dasarkan pada pengelompokaan jenis industri pada Indonesian Capital Market Dictionary (ICMD). Kelompok pertama primary sector, yang terdiri dari Agriculture, Forestry and Fishing, Animal Feed and Husbandry, Minning and Minning Services, dan construction. Kelompok kedua adalah perusahaan manufaktur (secondary sector) yang terdiri dari Food and Beverages, Tobacco Manufactures, Textile mill Products, Apparel and Other Textile Products, Lumber and Wood Products, Paper and Allied Products, Chemical and Allied Products, Adhesive, Plastics and Glass Products, Cement, Metal and Allied Products, Fabricated Metal Products, Stone, Clay, Glass and Concrete Products, Machinery, Cable, Electric and Electronic Equipment, Automotive and Allied Products, Photographic Equipment, Pharmaceuticals, Consumer Goods, Transportation Services, Communication, dan Wholesale and Retail Trade. Kelompok ketiga adalah tertiary sector yang terdiri dari sektor insurance, Real Estate and Property, Hotel and Travel Services, Holding and Other Investment Companies, dan lainnya. Dengan menghitung rata-rata tax avoidance jangka panjang serta tax avoidance jangka pendek pada masing-masing kelompok pada masing-masing tahun. Hasilnya perhitungan tax avoidance disajikan pada gambar 4.

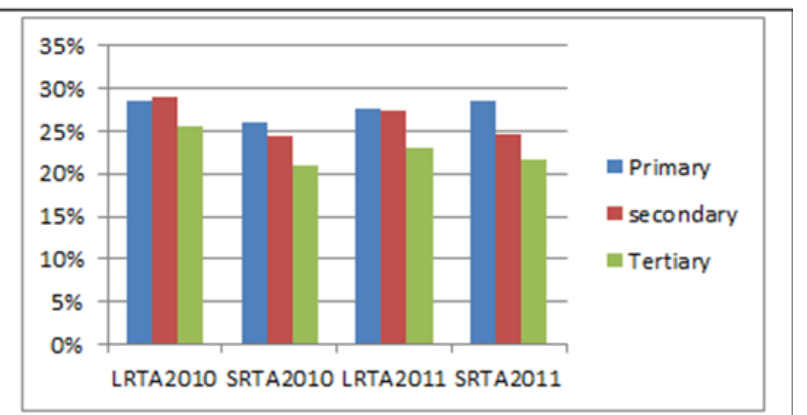

\begin{tabular}{|l|r|r|r|r|}
\hline Sector & LRTA2010 & SRTA2015 & LRTA2016 & SRTA2016 \\
\hline Primary & $28.59 \%$ & $25.92 \%$ & $27.57 \%$ & $28.54 \%$ \\
\hline Secondary & $28.99 \%$ & $24.44 \%$ & $27.41 \%$ & $24.76 \%$ \\
\hline Tertiary & $25.53 \%$ & $20.94 \%$ & $23.16 \%$ & $21.69 \%$ \\
\hline
\end{tabular}

Gambar 4. Tax Avoidance Jangka Panjang pada Tiga Sektor di BEI

Pengujian Pengaruh Tax Avoidance Jangka pendek Terhadap Tax Avoidance Jangka panjang (Model 1)

Pengujian model 1 digunakan untuk menguji hipotesis 1, menguji pengaruh tax avoidance jangka pendek terhadap tax avoidance jangka panjang. Hasil pengujian dapat dilihat pada tabel 3. Dari hasil regresi pada tabel 3 menunjukkan hasil signifikan positif pada tingkat $1 \%$. Arah hubungan sesuai dengan prediksi yang berarti bahwa $\mathrm{H} 1$ diterima, tax avoidance jangka pendek berpengaruh positif terhadap long tun tax avoidance. Nilai p-value dari Fstate menunjukkan hasil yang signifikan dibawah $1 \%$ dan nilai adjusted Rsquare sebesar $78,60 \%$ menunjukkan bahwa tax avoidance jangka pendek merupakan variabel yang berpengaruh terhadap tax avoidance jangka panjang.

Tabel 3. Hasil regresi Model 1

\begin{tabular}{llll}
\hline Variabel & Prediksi & Koefisien & Prob. \\
\hline Konstanta & & 0,26035 & $0,0000^{* * *}$ \\
SRTA & - & 0,063871 & $0,0000^{* * *}$ \\
R $^{2}$ Adjusted & 0,786 & & \\
FStat & 8,311768 & & \\
p-value & $0,000^{* * *}$ & & \\
\hline
\end{tabular}

Keterangan: *** untuk signifikan $1 \%$, ** untuk signifikan $5 \%$ dan * signifikan $10 \%$. LRTA10 adalah tax avoidance jangka panjang yang dilakukan oleh perusahaan dengan jangka waktu 10 tahun.; SRTA merupakan tax avoidance jangka pendek yang dilakukan oleh perusahaan pada tahun 2015 dan tahun 2016. Dalam eviews, nilai $p$-value pada t-statistik merupakan pengujian untuk 2 arah, karena pengujian merupakan pengujian 1 arah, maka nilai $p$-value dari t-statistik dibagi 2.

Tabel 4. Independent sample t-test

\begin{tabular}{llll}
\hline Nama Variabel & SRTA & & LRTA10 \\
& $<$ mean & $\geq$ Mean & \\
\hline Rata -rata & $25,20 \%$ & $29,92 \%$ & $27,56 \%$ \\
Jumlah observasi & \multicolumn{2}{c}{210} & 210 \\
F- stat & \multicolumn{2}{c}{6.787} & \\
p-value & $0.003^{* * *}$ & \\
\hline
\end{tabular}

Dari hasil pengujian independent sample t-test (tabel 4), hasilnya menunjukkan probabilitas dibawah $1 \%$. Hal ini berarti terdapat perbedaan antara tax avoidance jangka panjang pada perusahaan dengan tax avoidance jangka pendek yang tinggi dengan perusahaan dengan tax avoidance jangka pendek yang rendah.

\section{Pengujian Persistensi Tax Avoidance Jangka Pen- dek (Model 2)}

Pengujian model 2 digunakan untuk menguji hipotesis 2 dan hipotesis 3 dengan menguji persistensi dari tax avoidance jangka pendek yang dilakukan oleh perusahaan di Indonesia, serta dengan memoderasi persistensi dengan tinggi-rendahnya tax avoidance jangka pendek perusahaan. Tinggi rendahnya tax avoidance jangka pendek ditentukan oleh median tax avoidance jangka pendek dimana tax avoidance dinyatakan tinggi untuk ETR tahunan yang berada diatas median dan tax avoidance jangka pendek rendah adalah perusahaan dengan ETR tahunan 
dibawah median. Hasil pengujian dapat dilihat pada tabel 5.

Hasil regresi seperti disajikan pada tabel 5 menunjukkan hasil signifikan negatif pada tingkat $1 \%$, menunjukkan bahwa tax avoidance jangka pendek yang dilakukan oleh perusahaan persisten dari tahun ke tahun. Hal tersebut menunjukkan bahwa hipotesis 2 dalam penelitian ini diterima. Selain itu, untuk hasil pemoderasian antara SRTAt dengan dummy SRTA menunjukkan hasil signifikan positif dengan $p$-value dibawah 5\%. Hasil tersebut menunjukkan bahwa tinggi-rendahnya ETR tahunan yang dibayarkan oleh perusahaan mempengaruhi persistensi dari tax avoidance jangka pendek perusahaan. dari hasil tersebut dapat disimpulkan bahwa $\mathrm{H} 3$ dalam penelitian ini diterima, ETR tahunan yang lebih rendah cenderung lebih persisten dari tahun ke tahun. Secara global, pengujian Fstatistik memiliki nilai $p$-value dibawah $1 \%$ dan nilai adjusted Rsquare sebesar $31,86 \%$.

Tabel 5. Hasil Regresi Model 2

\begin{tabular}{llll}
\hline Variabel & Prediksi & Koefisien & Prob. \\
\hline Konstanta & & 0,229199 & $0,0000^{* * *}$ \\
SRTAt & - & 0,22609 & $0,0000^{* *}$ \\
STRAt*d_SRTA & + & 0,070427 & $0,0127^{* *}$ \\
R $^{2}$ Adjusted & 0,3187 & & \\
F $_{\text {Stat }}$ & 5,6129 & & \\
p-value & $0,000^{* * *}$ & &
\end{tabular}

Keterangan: *** signifikan $1 \%$; ${ }^{* *}$ signifikan $5 \%$ dan * signifikan $10 \%$. SRTAt adalah tax avoidance jangka pendek yang dihitung dengan ETR tahunan; SRTAt+1 merupakan tax avoidance jangka pendek yang dilakukan oleh perusahaan periode tahun berikutnya. Dalam eviews nilai $p$-value dari t-statistik untuk hipotesis 2 arah dibagi dua.

\section{PEMBAHASAN}

Pengujian pengaruh tax avoidance jangka pendek terhadap tax avoidance jangka panjang (Model 1)

Berdasarkan hasil analisis menunjukkan tax avoidance jangka pendek berpengaruh positif terhadap long tun tax avoidance. Peneliti melakukan uji beda tax avoidance dalam pengukuran jangka panjang dan jangka pendek dengan independent sample $t$-test. Dari hasil pengujian independent sample $t$-test, hasilnya menunjukkan terdapat perbedaan antara tax avoidance jangka panjang pada perusahaan dengan tax avoidance jangka pendek yang tinggi dengan perusahaan dengan tax avoidance jangka pendek yang rendah.

\section{Persistensi Tax Avoidance jangka Pendek Model 2}

Hasil pengujian persistensi dari tax avoidance jangka pendek yang dilakukan oleh perusahaan di Indonesia, dengan memoderasi persistensi dengan tinggi-rendahnya tax avoidance jangka pendek perusahaan menunjukkan Tinggi rendahnya tax avoidance jangka pendek ditentukan oleh median tax avoidance jangka pendek. Dimana tax avoidance dinyatakan tinggi untuk ETR tahunan yang berada diatas median dan tax avoidance jangka pendek rendah adalah perusahaan dengan ETR tahunan dibawah median. Selain itu, untuk hasil pemoderasian antara SRTAt dengan dummy SRTA menunjukkan hasil signifikan positif. Hasil tersebut menunjukkan bahwa tinggirendahnya ETR tahunan yang dibayarkan oleh perusahaan mempengaruhi persistensi dari tax avoidance jangka pendek perusahaan. Hasil tersebut dapat disimpulkan bahwa ETR tahunan yang lebih rendah cenderung lebih persisten dari tahun ke tahun.

\section{SIMPULAN DAN SARAN}

Perilaku tax avoidance jangka pendek pada perusahaan di Indonesia bersifat persisten dari tahun ke tahun. Selain itu, untuk tax avoidance jangka pendek yang rendah (ETR tahunan yang tinggi) cenderung lebih persisten dibanding dengan tax avoidance jangka pendek yang tinggi. Persistensi tax avoidance dalam penelitian ini menggunakan periode 10 tahun, yaitu dari tahun 2007 sampai dengan tahun 2016. Penelitian ini baru mengkaji long run tax avoidance selama 2 tahun yaitu tahun 2015 dan tahun 2016. Hendaknya untuk penelitian selanjutnya dapat menambah periode penelitian dengan periode long run tax avoidance yang dihitung kumulatif 10 tahun. Dengan adanya pengaruh tax avoidance jangka pendek terhadap tax avoidance jangka panjang, untuk penelitian selanjutnya tax avoidance jangka pendek dapat diuji sebagai variabel intervening antara karakteristik perusahaan dengan tax avoidance jangka panjang karena karakteristik perusahaan yang digunakan dalam penelitian ini telah lebih banyak diuji pengaruhnya terhadap tax avoidance jangka pendek.

\section{DAFTAR PUSTAKA}

Amri, Muhtadin. (2017). Pengaruh Kompensasi Manajemen Terhadap Penghindaran Pajak Dengan Moderasi Diversifikasi Gender Direksi dan Preferensi Risiko Eksekutif Perusahaan di Indonesia. Jurnal Aset (Akuntansi Riset). Vol.9 (1)

Aprilliana, Ernawati dan Intiyas Utami. (2007). Pengaruh Konsep Pajak, political cost dan Agency terhadap Kebijakan akuntansi Persediaan dan Nilai Perusahaan. Jurnal Akuntansi dan Keuangan. Vol.1(3): 219 - 234.

Baltagi, H. Bagi. (2005). Econometric Analysis of 
Panel Data. John Wiley \& Sons Canada.

Chain, P. (1997). Same or Different?: A Comparison of the Beliefs Australian and Chinese University Students Hold about Learning's Proceedings of AARE conference, Swisburne University. Available at: http://www.swin.edu.au/ aare/97pap/CHAN97058.html.

Damayanti, Fitir, dan Susanto, Tridahus. (2015). Pengaruh Komite Audit, Kualitas Audit, Kepemilikan Institusional, Risiko Perusahaan, dan Return on Assets Terhadap Tax Avoidance. ESENSI Jurnal Bisnis dan Manajemen. Vol. 5(2)

Dyreng, Scott, Michelle Hanlon dan Edward Maydew. (2008). Long Run Corporate Tax Avoidance. The Accounting Review. 83 (1): 6182.

Irawan, Yanuar. Sularso, Havid dan Farida, Nur Yusriati. (2017). Analisis atas Penghindaran Pajak (Tax Avoidance) Pada Perusahaan Properti dan Real Estate di Indonesia. Soedirman Accounting Review. Vol. 02(02).

Nachrowi, D. Nachrowi. (2006). Pendekatan Populer dan Praktis Ekonometrika Untuk Analisis Ekonomi dan Keuangan. Jakarta: Lembaga Penerbit Fakultas Ekonomi Universitas Indonesia.

Richardson dan Lanis. (2007). Determinant of the variability in corporate effective tax rates and tax reform: Evidence from Australia. Journal of Accounting and Public Policy. Vol. 26(6): 689-704

Pratiwi, Siti Indriati. (2017). The Role of Corporate Political Connections in the Relation of CSR and Tax Avoidance: Evidence from Indonesia. Review of Integrative Business and Economics Research, Vol. 6, Supplementary Issue 1

Sakina H, Dita. (2010). Faktor-Faktor yang Mempengaruhi Variasi ETR Perusahaan. Skripsi. FE UI.

Soepriyanto, Gatot. (2008). Faktor-faktor yang Mempengaruhi Variasi Tarif Pajak Effective Perusahaan: Study Terhadap Perusahaan yang Terdaftar di Bursa Efek Indonesia Periode 2002-2006. The 2nd Accounting conference 1st doctoral colloqium and accounting workshop, 4-5 November 2008.

Sukarman, W. (2003). Liberalisasi: Ekonomi Politik Perbankan Masa Orde Baru [Liberalisation: Banking Economy-Politic in Orde Baru Area]. Unpublished Dissertation. PostGraduate Programme. Yogyakarta: UGM.

Yuniarwati. Ardana, I Cenik. Dewi, Sofia Prima, dan Lin, Caroline. (2017). Factors That In- fluence Tax Avoidance in Indonesia Stock Exchange. Chinese Business Review, Oct. 2017, Vol. 16, No. 10, 510-517 